\title{
Expression of Circulating Microparticles for the Diagnosis of Non-small Cell Lung Cancer: Clinicopathological Correlations and Prognostic Value
}

\author{
Fadi Najjar ${ }^{1, *}$, Moosheer Alammar ${ }^{2}$, Ghassan Al-Massarani ${ }^{1}$, Abdulmonem Japawe $^{3}$, \\ Nissreen Alamalla ${ }^{1}$, Issraa Banat ${ }^{1}$, Adnan Ikhtiar ${ }^{3}$ \\ ${ }^{1}$ Biomarkers Laboratory, Department of Radiation Medicine, Atomic Energy Commission of Syria (AECS), Syria \\ ${ }^{2}$ Division of Thoracic Oncology, Department of Oncology, Albairouni University Hospital, Syria \\ ${ }^{3}$ Radiobiology Laboratory, Department of Biotechnology, Atomic Energy Commission of Syria (AECS), Syria
}

Received March 17, 2020; Revised April 27, 2020; Accepted May 3, 2020

Copyright $(\mathcal{O} 2020$ by authors, all rights reserved. Authors agree that this article remains permanently open access under the terms of the Creative Commons Attribution License 4.0 International License

\begin{abstract}
Increased values of circulating microparticles (MPs) have been reported in solid tumors including non-small cell lung cancer (NSCLC). We therefore investigated the utility of baseline MPs in the clinical setting of patients with NSCLC. Quantification of MPs in the plasma was performed by flowcytometry. Baseline MP values were correlated with clinical patients' characteristics, estimated tumor volume (ETV) and treatment response. Receiver operating characteristics (ROC) curves were plotted to discriminate between patients and controls in order to determine the diagnostic value of circulating MPs in NSCLC. Our prospective study included 134 NSCLC patients (98 at initial diagnosis, ID and 36 at relapse, $\mathrm{R}$ ) and 30 healthy individuals. The mean of baseline MP numbers was significantly higher in patients presented either at ID or $\mathrm{R}$ than in controls $(p<0.0001)$. Basal MP numbers were inversely correlated with ETV values $(p=0.04)$. In addition, the difference in MP levels at diagnosis was significant according to tumor histology $(p=0.02)$ and primary tumor size $(p=0.0007)$. Using ROC analysis, the optimal cutoff value for baseline MPs was 1307 events $/ \mu \mathrm{L}$ with a sensitivity and a specificity of $67.3 \%$ and $90.0 \%$, respectively. High MPs expression was significantly associated with low-level smoking degree $(p=0.001)$, non-squamous cell types $(p=0.017)$ and decreased tumor size $(p=0.003)$. Our results suggest that high baseline MP values could be an indicator of tumor growth inhibition in NSSLC. Furthermore, high expression of circulating MPs at diagnosis might predict good prognosis in NSCLC patients.
\end{abstract}

Keywords Biomarkers, Clinicopathological Features, Microparticles, Non-small Cell Lung Cancer

\section{Introduction}

Non-small cell lung cancer (NSCLC) represents about $85 \%$ of lung cancer (LC) cases, and most patients have metastatic disease at their initial diagnosis [1]. However, NSCLC patients with locally-advanced stages are treated by surgery, chemotherapy and radiotherapy. It should be noted that surgical outcomes with lymph nodes dissection and intraoperative blood loss were significantly related to postoperative complications [2]. Adjuvant chemotherapy improved survival in patients with completely resected early-stage NSCLC, while standard chemotherapy relatively prolonged survival rate in NSCLC patients at advanced stages, but it is still low with 5-year survival rate of $2 \%$ [3-5]. Recently, molecularly targeted drugs have been introduced such as tyrosine kinase epidermal growth factor receptor (EGFR) inhibitors and anaplastic lymphoma tyrosine kinase (ALK) inhibitors [6]. These targeted drugs have become the treatment of choice for NSCLC patients with mutations in EGFR and ALK genes $[7,8]$.

There is an urgent need for new diagnostic strategies to screen individuals at high risk for reducing LC mortality rate in NSCLC [9]. However, clinicopathological characteristics of patients have been previously proposed as prognostic factors in NSCLC. In fact, the determination of correct prognostic factors may predict disease outcome in LC. Therefore, the identification of an effective marker is essential for NSCLC to predict clinical outcome. Recently, better understanding of molecular biology of NSCLC have attracted attention for molecular-driven 
targeted therapy. So it is warranted to develop new biomarkers that can be easily applied in the clinical setting in order to improve the therapeutic outcome of NSCLC [10]. Disappointingly, no effective biomarker has been yet clinically validated for the evaluation of newly diagnosed LC patients.

Circulating microparticles (MPs), which are small vesicles $(0.1-1 \mu \mathrm{m})$ in diameter, can be released in the peripheral blood by activated or apoptotic cells $[11,12]$. They are resulting from vesiculation of platelet plasma membrane and other blood cells and could be detected in fresh-frozen plasma as circulating MPs [13]. The exposure of phospholipids and phosphatidyl serine on the surface of MPs could be derived from platelets and endothelial cells. These MPs may also most likely express tissue factor (TF) and be potential inducer of procoagulation [14]. Accordingly, it has been demonstrated that MPs expressing phosphatidylserine have an important role in blood coagulation and thrombosis $[15,16]$. In fact, TF activity on tumor cells could be potentially mediated by the expression of anionic phospholipids on the outer leaflet of cell membrane $[17,18]$. In addition, it has been found that MPs especially those derived from platelets play an important role in angiogenesis [16]. Actually, they promote capillary like structures and production of proangiogenic factor $[19,20]$. Thus, increased MP values have been reported in many tumor types including hematological malignancies and breast cancer [21,22]. However, the clinical utility of MPs in NSCLC is still undefined. We therefore investigated the potential clinical value of circulating MPs as diagnostic and prognostic tool in NSCLC.

\section{Patients and Methods}

\subsection{Cohort Selection}

Between August 2015 and February 2017, we restricted our analyses to patients diagnosed with histologically confirmed NSCLC of more than 18 years-old and Eastern Cooperative Oncology Group (ECOG) performance status (PS) of $\leq 2$. Our patients presented at the department of Thoracic Oncology in Albairouni University Hospital either at initial diagnosis (ID) or at relapse (R). Detailed clinical characteristics and follow-up data including age, gender, pathological, computed tomography (CT) and bone scans findings, were prospectively collected for analysis. To circumvent adverse influence on MPs measurement, patients with recent surgery or trauma during the preceding 2 months, history of other malignancy or febrile disease, chronic kidney failure, heart disease, liver cirrhosis, hematologic disorders, current use of anti-platelet agents, acute or chronic inflammatory, and autoimmune disease were excluded from the study.

\subsection{Data Collection}

Blood samples were collected from patients and healthy individuals. Smoking degree was considered according to the number of packs per year. A pack-year $(\mathrm{P} / \mathrm{Y})$ is defined as the number of packs of cigarettes a person smoked every day multiplied by the number of years the patient has smoked. With regard to smoking degree, the patients being considered as heavy smokers for those who smoked more than $15 \mathrm{P} / \mathrm{Y}$, while low-level smoking degree was considered for those who smoked less than $15 \mathrm{P} / \mathrm{Y}$.

Recent weight loss was considered for patients who had lost during the last three months more than $5 \%$ of their body weight or less than $2 \%$ for those with body mass index (BMI) less than 20. The remaining patients were considered without recent weight loss.

According to tumor histology, our patients were divided into two groups: patients with squamous cell type and those with non-squamous cell types. Our population were also classified according to tumor histological grade into patients with well-moderately differentiated grade and those with poorly differentiated grade.

The included patients were either at initial diagnosis (ID) or at relapse (R). Then, all NSCLC cases were staged by chest and abdominal computed tomography (CT). According to radiological findings based on the American Joint Committee on Union for International Cancer Control Criteria, our population was divided into two groups: patients with early stages (stage I to IIIA) and those with locally-advanced and metastatic stages (stage IIIB, IV).

Estimated tumor volume (ETV) was determined according to CT findings by measuring the major axis (a) and the minor axis (b) of the primary tumor using the following formula:

$$
\text { ETV }=\frac{4}{3} \times \pi\left[\left(\frac{a}{2} \times \frac{b}{2}\right) \times\left(\frac{a}{2}+\frac{b}{2}\right)\right] \div 2
$$

Follow-up data were collected until August 2018. The therapeutic efficacy was evaluated according to response evaluation criteria for solid tumors (RECIST) [23]. An objective response (OR) was identified in patients who had partial response (PR) or stable disease (SD) after treatment. However, progression disease (PD) was defined when the patient had an increase of more than $20 \%$ in the longest diameter of the tumor mass or the appearance of new metastases on $\mathrm{CT}$ after chemotherapy.

Pretreatment MP values were correlated with clinical characteristics of NSCLC patients including gender, age, smoking history, BMI, clinical presentation, histological type, ETV, staging and treatment response. According to their cutoff value, MP levels were correlated with clinicopathological parameters of our patients including gender, age, smoking degree, recent weight loss, clinical presentation, tumor histology, pathological grade, primary tumor size, clinical stage and treatment response.

\subsection{Isolation and Quantification of Circulating MPs by Flow Cytometry}

Peripheral blood samples were collected in vacutainer 
tubes containing acid citrate dextrose (ACD) as anti-coagulant. Blood samples were analyzed using protocol out lined previously [24]. Then, they were kept at $(4-8)^{\circ} \mathrm{C}$ and processed within 24 hours after collection. Whole-blood was centrifuged at $2500 \mathrm{xg}$ for 15 minutes at $4^{\circ} \mathrm{C}$ without acceleration to prepare platelet-rich plasma. Then, plasma samples were centrifuged at $19800 \mathrm{~g}$ for 10 min. The supernatant was transferred to a new tube and centrifuged at $13000 \mathrm{~g}$ for $5 \mathrm{~min}$ at room temperature in order to obtain platelet-free plasma (PFP), which was divided into two aliquots of $200 \mu \mathrm{l}$. If needed, aliquots of PFP were stored at $-80^{\circ} \mathrm{C}$ for later batch analysis. According to the manufacturer's instructions, standard fluorescent beads (Megamix, BioCytex, Marseille, France) of different diameters $(0.5-3 \mu \mathrm{m})$ were used for size calibration and to set the gate for MP detection. Then $10-\mu \mathrm{L}$ pellet of MPs was diluted with $490 \mu \mathrm{L}$ of AnnexinV binding buffer, and incubated in a TruCOUNT tube with FITC anti-AnnexinV (BioVision, Milpitas, CA, USA). Isolated MPs were identified as particles $<1.0 \mu \mathrm{m}$ in diameter and positively stained with FITC-Annexin V. The amount of MPs was expressed as events/ $\mu \mathrm{L}$ of plasma.

\section{Statistical Analysis}

Data were expressed as means \pm standard error of the mean (SEM). Analysis of variance (ANOVA) was used to determine the differences in MP levels. Continuous variables were analyzed by independent $t$-test, while Pearson's chi-square test was used to analyze categorical variables. The diagnostic accuracy of circulating MP levels to distinguish between patients and controls was assessed using receiver operating characteristic (ROC) curves. Sensitivity and specificity were calculated for different cut-off values, and the optimal cut-off value for MP numbers were determined using ROC analysis. The overall performance of ROC analysis was quantified by computing the area under curve (AUC). All statistical analyses were conducted using statistical package social sciences software for windows, version 15.0 (SPSS Inc., Chicago, IL, USA). All statistical tests were two-tailed and $p$ value $\leq$ 0.05 were considered statistically significant.

\section{Results}

\subsection{Patients' Characteristics and Baseline MP Values}

A total of 134 NSCLC patients (113 men, 21 women), presented at ID $(n=98)$ or at $\mathrm{R}(\mathrm{n}=36)$ and 30 healthy volunteers (25 men, 5 women), were prospectively included in this study. The main clinical characteristics of patients were correlated with baseline MP values as shown in the Table 1 . The mean age of patients was significantly higher than that in healthy subjects (mean \pm SEM: $55.42 \pm$ 8.99 vs. $37.13 \pm 6.89$ years, $p<0.0001$ ). However, basal MP numbers were not significantly correlated with increasing age in patients $(p=0.81)$. The mean of baseline MP numbers was significantly higher in patients either at ID or $\mathrm{R}$ than in controls (mean \pm SEM: $2902 \pm 264$ and $2753 \pm$ 442 , respectively vs. $780 \pm 106, p<0.0001$ ), figure (1). However, the difference in their numbers was not significantly different between patients at ID and those at $\mathrm{R}$ (mean \pm SEM: $2902 \pm 264$ vs. $2753 \pm 442, p=0.75$ ). Additionally, no significant difference in circulating MP values at diagnosis was obtained according to patients' characteristics including gender $(p=0.96)$, age $(p=0.53)$, BMI $(p=0.56)$, and smoking status $(p=0.73)$. Moreover, there was no significant difference in basal MP numbers between patients at early stages and those at advanced stages (mean \pm SEM: $2704 \pm 451$ vs. $2916 \pm 298, p=0.47$ ).

Table 1. Baseline MP values and clinical characteristics of non-small cell lung cancer patients

\begin{tabular}{|c|c|c|c|c|}
\hline Clinical characteristics & & $\mathrm{N}^{\circ}(\%)$ & $\begin{array}{c}\text { MPs value } \\
\text { Mean } \pm \text { SEM }\end{array}$ & $p$-value \\
\hline $\begin{array}{c}\text { Patients } \\
\text { Healthy controls }\end{array}$ & Number & $\begin{array}{c}134 \\
30 \\
\end{array}$ & $\begin{array}{c}2862 \pm 372 \\
780 \pm 106 \\
\end{array}$ & $p<0.0001^{*}$ \\
\hline Gender & $\begin{array}{c}\text { Male } \\
\text { Female }\end{array}$ & $\begin{array}{c}113(84.3) \\
21(15.7) \\
\end{array}$ & $\begin{array}{l}2863 \pm 220 \\
2835 \pm 616 \\
\end{array}$ & 0.96 \\
\hline Age & $\begin{array}{l}\leq 60 \text { years } \\
>60 \text { years }\end{array}$ & $\begin{array}{l}92(68.7) \\
42(31.3) \\
\end{array}$ & $\begin{array}{l}2835 \pm 616 \\
3074 \pm 480 \\
\end{array}$ & 0.53 \\
\hline Clinical presentation & $\begin{array}{l}\text { ID } \\
\mathrm{R}\end{array}$ & $\begin{array}{l}98(73.1) \\
36(26.9)\end{array}$ & $\begin{array}{l}2902 \pm 293 \\
2689 \pm 464\end{array}$ & 0.75 \\
\hline Histological type & $\begin{array}{c}\text { SCC } \\
\text { Non-SCC }\end{array}$ & $\begin{array}{l}55(46.2) \\
64(53.8)\end{array}$ & $\begin{array}{l}2281 \pm 308 \\
3355 \pm 419\end{array}$ & $0.02 *$ \\
\hline Pathological grade & $\begin{array}{c}\text { Well/moderate } \\
\text { Poor }\end{array}$ & $\begin{array}{l}52(53.6) \\
45(46.4) \\
\end{array}$ & $\begin{array}{l}2515 \pm 349 \\
2435 \pm 363 \\
\end{array}$ & 0.86 \\
\hline Primary tumor size (major axis) & $\begin{array}{l}>4 \mathrm{~cm} \\
\leq 4 \mathrm{~cm}\end{array}$ & $\begin{array}{l}50(60.7) \\
33(39.3)\end{array}$ & $\begin{array}{l}3611 \pm 509 \\
1846 \pm 324\end{array}$ & $0.0007^{*}$ \\
\hline TMN Staging & $\begin{array}{c}\text { Early } \\
\text { Advanced }\end{array}$ & $\begin{array}{l}36(26.9) \\
98(73.1)\end{array}$ & $\begin{array}{l}2704 \pm 450 \\
1916 \pm 298 \\
\end{array}$ & 0.68 \\
\hline Response to chemotherapy & $\begin{array}{c}\mathrm{PR} / \mathrm{SD} \\
\mathrm{PD}\end{array}$ & $\begin{array}{l}77(66.4) \\
39(33.6) \\
\end{array}$ & $\begin{array}{l}2886 \pm 328 \\
2959 \pm 477 \\
\end{array}$ & 0.85 \\
\hline
\end{tabular}

MPs: microparticles; SCC: squamous cell carcinoma; P/Y: pack-years; ID: initial diagnosis; R: relapse; dif: differentiated, TNM: tumor-node-metastases; PR: partial response; SD: stable disease; PD: progression disease; *: $p \leq 0.05$ 


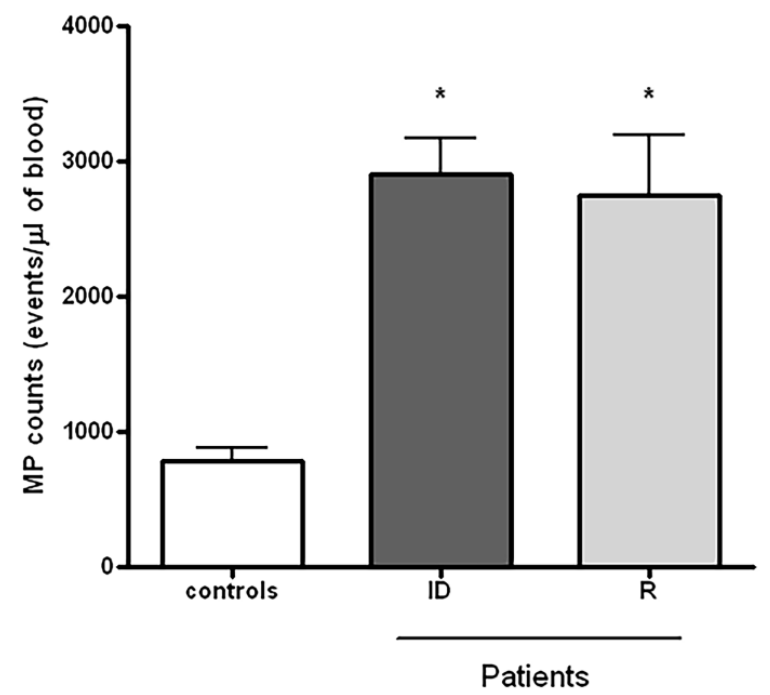

Figure 1. Baseline microparticles (MP) levels (events $/ \mu \mathrm{L}$ ) in patients with non-small cell lung cancer (NSCLC) and in healthy subjects. Basal MP values were significantly higher in patients at initial diagnosis (ID) and relapse (R) than in healthy subjects $(p=0.007$ and $p<0.0001$, respectively). There was no significant difference in basal MPs numbers between patients at ID and those at $\mathrm{R}(p=0.75)$

Although no significant difference in basal MP values was observed according to histological grade $(p=0.86)$, higher pretreatment MP numbers were obtained in patients with non-squamous cell types compared to those with squamous cell carcinoma ( $p=0.02)$, figure (2).

Pretreatment MP values were inversely correlated with ETV numbers in 83 assessable patients $(p=0.002)$, figure (3). Moreover, baseline MP values were significantly higher in patients with primary tumor size less than $4 \mathrm{~cm}$ than in those with primary tumor size more than $4 \mathrm{~cm}$ (mean \pm SEM: $2611 \pm 509$ vs. $1846 \pm 324, p=0.0007$ ).

On the other hand, clinical follow-up data were available in 116 patients for the evaluation treatment response showing an OR in 77 patients and PD in 39 patients. Data analysis revealed that there was no significant difference in the mean of baseline MPs numbers between patients with OR and those with PD after treatment (mean \pm SEM: 2856 $\pm 328 v$ s. $2959 \pm 477, p=0.85$ ).

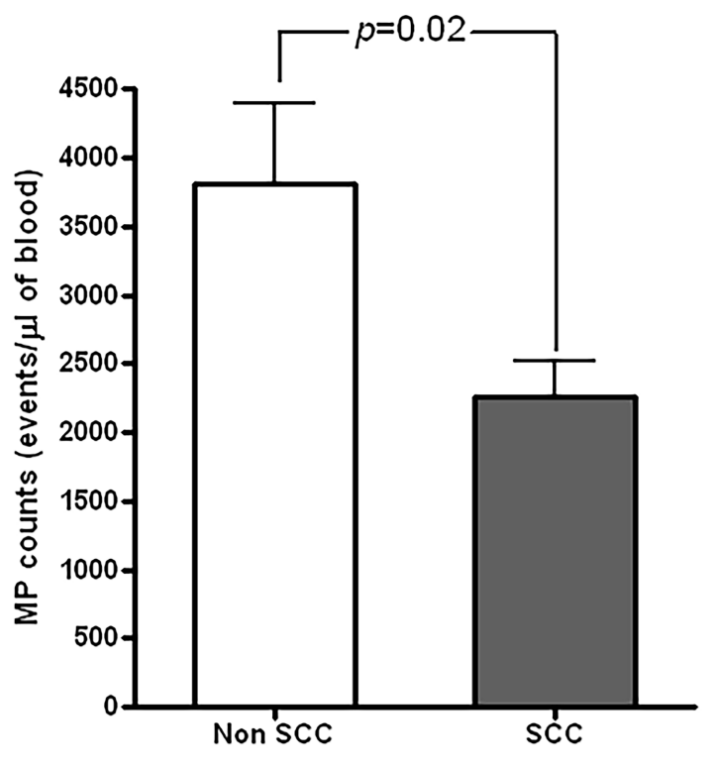

Figure 2. Pretreatment microparticles (MP) levels in non-small cell lung cancer (NSCLC) patients according to histological subtypes. Circulating MP levels were significantly higher in patients with non-squamous cell types than those in patients with squamous cell type $(p=0.02)$

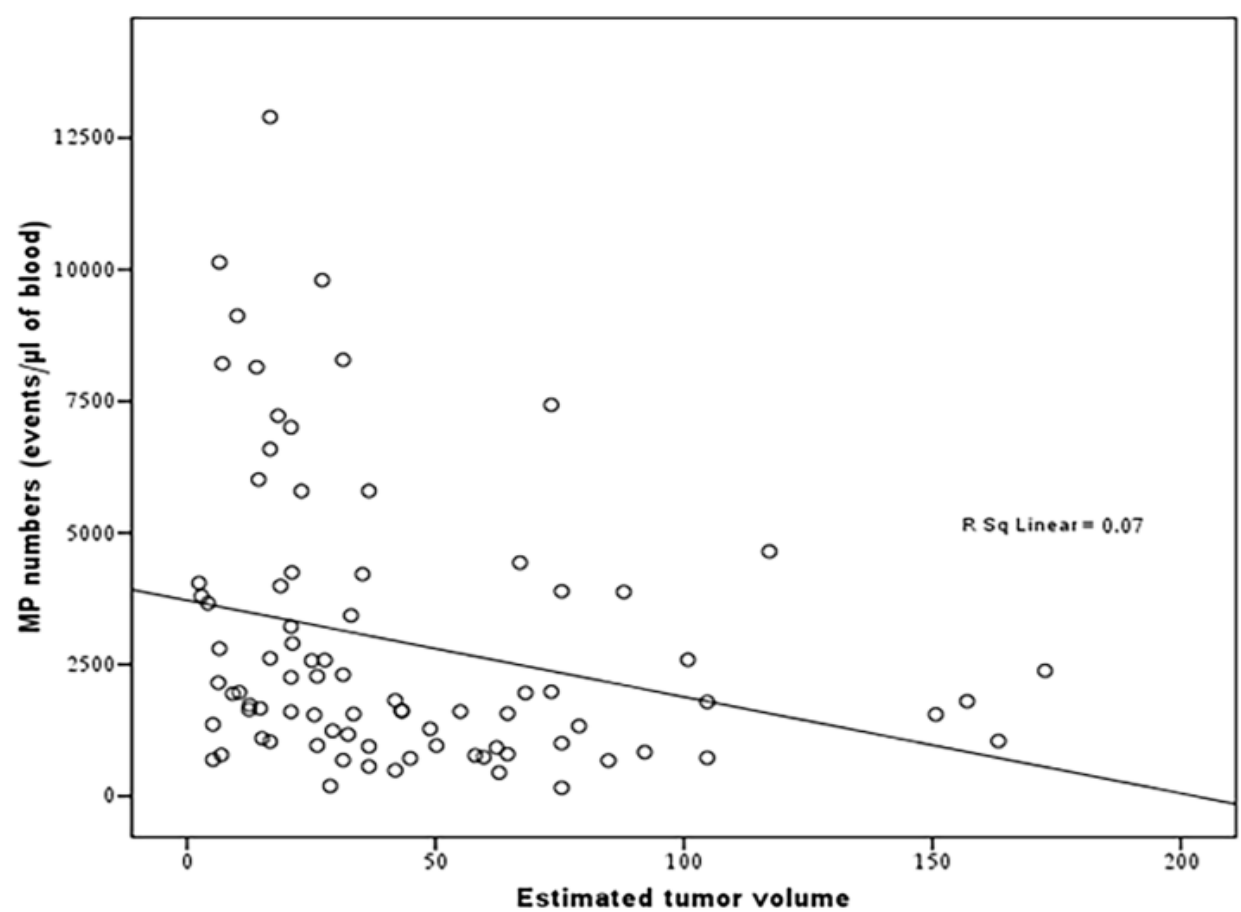

Figure 3. Scatter plot analysis to correlate basal microparticles (MP) numbers with estimated tumor volume (ETV) values in patients with non-small cell lung cancer (NSCLC). Basal MP numbers were inversely correlated with ETV values $\left(\mathrm{r}^{2}=0.07, p=0.002\right)$ 


\subsection{Circulating MPs Expression and Clinicopathological Parameters}

As illustrated in figure (4), ROC curves analysis showed that AUC was 0.847 which significantly differs from 0.5 $(p<0.002)$. The best efficacy for baseline MP numbers was observed at 1307 events $/ \mu \mathrm{L}$ with a sensitivity and a specificity of $67.3 \%$ and $90.0 \%$, respectively. According to this value, 92 and 42 patients showed high and low MPs expression, respectively. As shown in Table (2), high expression of circulating MPs was significantly associated with low-level smoking degree $(p=0.001)$, non-squamous cell histological types $(p=0.017)$, and decreased primary tumor size $(p=0.003)$. However, MPs expression was not significantly correlated with the other clinicopathological parameters including gender, age, estimated weight loss, clinical presentation, histological grade, staging, and treatment response (all $p>0.05$ ).

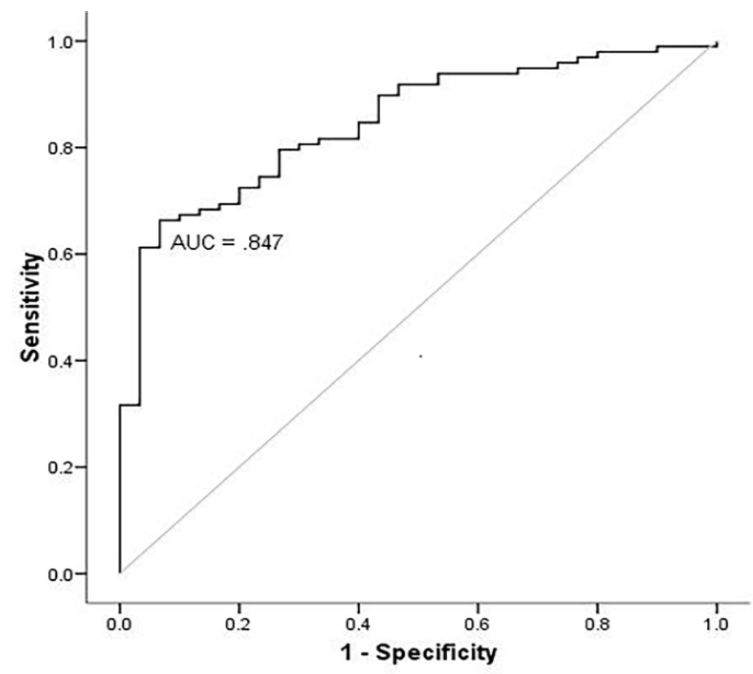

Figure 4. Receiver operating characteristic (ROC) curve of circulating microparticles (MPs) for the discrimination between patients and healthy controls. AUC: area under curve

Table 2. Relationship between circulating MPs expression and clinicopathological features of NSCLC patients

\begin{tabular}{|c|c|c|c|c|c|c|}
\hline Clinicopathological features & & $\mathrm{N}^{\mathrm{o}}$ & $\begin{array}{c}\text { Low MPs } \\
\text { expression } \mathrm{N}^{\circ}(\%)\end{array}$ & $\begin{array}{c}\text { High MPs } \\
\text { expression } \mathrm{N}^{\circ}(\%)\end{array}$ & Chi-squared & $p$-value \\
\hline Gender & $\begin{array}{l}\text { Male } \\
\text { Female }\end{array}$ & $\begin{array}{c}113 \\
21\end{array}$ & $\begin{array}{l}32(28.3) \\
10(47.6)\end{array}$ & $\begin{array}{l}81(71.7) \\
11(52.4)\end{array}$ & 0.166 & 0.96 \\
\hline Age (years) & $\begin{array}{l}\leq 60 \\
>60\end{array}$ & $\begin{array}{l}54 \\
80\end{array}$ & $\begin{array}{c}18(33.3) \\
24(30)\end{array}$ & $\begin{array}{c}36(66.7) \\
56(70)\end{array}$ & 0.166 & 0.71 \\
\hline Smoking degree & $\begin{array}{l}\leq 15 \mathrm{P} / \mathrm{Y} \\
>15 \mathrm{P} / \mathrm{Y}\end{array}$ & $\begin{array}{c}24 \\
110\end{array}$ & $\begin{array}{l}17(70.8) \\
36(32.7)\end{array}$ & $\begin{array}{c}7(29.2) \\
74(67.3)\end{array}$ & 12.144 & 0.001 \\
\hline Estimated weight loss & $\begin{array}{l}\text { None } \\
\text { Yes }\end{array}$ & $\begin{array}{l}47 \\
61\end{array}$ & $\begin{array}{l}14(29.8) \\
23(37.7)\end{array}$ & $\begin{array}{l}33(70.2) \\
38(62.3)\end{array}$ & 0.739 & 0.42 \\
\hline Clinical presentation & $\begin{array}{l}\mathrm{ID} \\
\mathrm{R}\end{array}$ & $\begin{array}{l}98 \\
36\end{array}$ & $\begin{array}{l}32(32.7) \\
10(27.8)\end{array}$ & $\begin{array}{l}66(67.3) \\
26(72.2)\end{array}$ & 0.291 & 0.68 \\
\hline Tumor histology & $\begin{array}{c}\text { SCC } \\
\text { Non-SCC }\end{array}$ & $\begin{array}{l}54 \\
69\end{array}$ & $\begin{array}{l}22(40.7) \\
14(20.3)\end{array}$ & $\begin{array}{l}32(59.3) \\
55(79.7)\end{array}$ & 6.120 & $0.017^{*}$ \\
\hline Pathological grade & $\begin{array}{l}\text { Well dif. } \\
\text { Poorly dif. }\end{array}$ & $\begin{array}{l}52 \\
45\end{array}$ & $\begin{array}{l}16(30.8) \\
17(37.8)\end{array}$ & $\begin{array}{l}36(79.2) \\
28(62.2)\end{array}$ & 0.528 & 0.52 \\
\hline Primary tumor size (major axis) & $\begin{array}{l}\leq 4 \mathrm{~cm} \\
>4 \mathrm{~cm}\end{array}$ & $\begin{array}{l}33 \\
50\end{array}$ & $\begin{array}{c}19(57.6) \\
12(24)\end{array}$ & $\begin{array}{c}14(42.4) \\
38(76)\end{array}$ & 9.577 & $0.003 *$ \\
\hline Staging & $\begin{array}{l}\text { I-IIIA } \\
\text { IIIB, IV }\end{array}$ & $\begin{array}{l}36 \\
98\end{array}$ & $\begin{array}{l}13(36.1) \\
29(29.6)\end{array}$ & $\begin{array}{l}23(63.9) \\
69(70.4)\end{array}$ & 0.520 & 0.52 \\
\hline Treatment response & $\begin{array}{c}\mathrm{PR} / \mathrm{SD} \\
\mathrm{PD}\end{array}$ & $\begin{array}{l}77 \\
39\end{array}$ & $\begin{array}{l}24(31.2) \\
13(33.3)\end{array}$ & $\begin{array}{l}53(68.8) \\
26(66.7)\end{array}$ & 0.176 & 0.68 \\
\hline
\end{tabular}

MPs: microparticles; SCC: squamous cell carcinoma; P/Y: pack-years; ID: initial diagnosis; R: relapse; dif: differentiated; PR: partial response; SD: stable disease; PD: progression disease; * $p<0.05$ 


\section{Discussion}

Angiogenesis is the formation of new blood vessels originating from an existing microvasculature $[25,26]$. This process occurs during pathological conditions such as cancer. However, tumor angiogenesis occurs when there is a local imbalance between proangiogenic and antiangiogenic factors [26]. The pathogenesis of blood coagulation activation in cancer is complex. However, thrombosis could be the first sign of malignant disease, preceding the clinical detection of cancer by months or even years [27]. Nevertheless, TF regulates tumor growth through angiogenesis and coagulation. The relationship between angiogenesis and TF expression has been previously reported in human NSCLC carcinoma [28]. However, the procoagulant activity of MPs expressing TF did not change. The process of fibrin formation and fibrinolysis parallels the development of malignancy, increasingly in those with metastases [29]. Clinicians tried to discover a useful biomarker for early detection of LC [30,31]. Actually, circulating MPs had differential roles in angiogenesis $[16,20]$. Alterations in subtle hemostatic, such as high levels of circulating MPs shed by tumor cells and platelets, are detected [32]. Furthermore, plasma MP numbers have been suggested as potential mediated signals for stimulating angiogenesis in solid tumors including LC [33].

It has been also proposed that the concentration of platelets-derived MPs, which represent the majority of MPs, may be an indicator of progression in NSCLC [34]. However, it has been found that MP numbers increased in NSCLC patients at early operable stages, but the difference in their levels was not significant between NSCLC patients three months after surgery and healthy controls [35]. These findings may explain why increased baseline MP values were observed in NSCLC patients either at ID or R in our study.

It has been demonstrated that circulating MPs increased in NSCLC patients diagnosed in end-stage compared with controls [36,37]. By contrast, higher baseline MP values have been found in NSCLC patients at early and advanced stages compared with those in healthy subjects in our study. Similar results have been also observed in a heterogeneous group of NSCLC and small-cell lung cancer (SCLC) patients $[34,38]$. Moreover, high MPs expression was also found in SCLC patients either at limited and or at extensive stages [39]. However, it has been suggested that cancer metastasis may be due to an effective gateway through lymphatic circulatory system [40]. This path way may be more efficient than direct metastatic dissemination from the primary tumor. These findings might explain why baseline MP values increased in LC patients either at early stages or at advanced stages.

Understanding the fundamental role of angiogenesis in cancer growth has led to a special interest regarding regulatory mechanisms for better management of cancer patients. Interestingly, we found that baseline MP numbers were inversely correlated with ETV values. Moreover, high basal MP values were associated with a decrease in the primary tumor size. However, it has been suggested that increased levels of monocyte-derived MPs might be an indicator of vascular complication in LC patients [34]. It has been also found that tumor size and neovascularization decreased after the injection of MPs in mice with lung carcinoma [41]. These results may explain why higher baseline MP levels were associated with a decrease in ETV values in our study.

It has been demonstrated that MPs may stimulate cellular proliferation and the adhesion of cancer cells that can affect vascular angiogenesis through the release of proangiogenic factors [42], suggesting that circulating MPs may predict treatment response in solid tumors including LC. By contrast, we found that there was no significant difference in the mean of baseline MP values between patients with OR and those with PD after chemotherapy. This discordance may due to the heterogeneity of our population, in which variable tumor response was obtained according to individual risk factors and clinical stages.

Finally, patients with non-squamous cell types and low-level smoking degree had high MPs expression in our study. However, high rate of positive EGFR mutation has been reported in these patients [43]. In fact, the thyroid transcription factor 1 (TTF-1) plays a physiologic role in the development and the morphogenesis of the thyroid and the lung during embryogenesis. It has been found that high expression of TTF-1 promote cancerization by regulating the activity of proliferating cells and new vessels formation, at least in lung adenocarcinoma [44]. This mechanism might be due the fact that TTF-1 was more frequently expressed in patients with adenocarcinoma compared to those with squamous cell lung carcinoma [45]. Moreover, it has been recently found that metabolic tumor volume demonstrated a significant difference between patients with wild-type and those with mutant EGFR especially when combined with smoking status [46]. We also found that high pretreatment MP numbers were associated with a decrease in ETV values. However, NSCLC patients with low-level smoking, high expression of TTF-1 and positive EGFR mutation showed good prognosis. Similarly, patients with non-squamous cell types and low-level smoking showed high baseline MP values in our study. These findings suggest that high MP values at diagnosis could be an indicator of good prognosis in NSCLC.

\section{Summary}

Taken together, our results not only extended the findings outlined in previous reports, but also provide a clinically relevant information suggesting baseline MPs as a useful potential biomarker in the clinical setting of NSCLC. We found that high basal MP values were 
associated with tumor growth inhibition in NSCLC patients. Moreover, high expression of circulating MPs was observed in patients with low-level smoking degree and non-squamous cell types, suggesting MPs expression at diagnosis as predictive tool of prognosis in NSCLC. Further studies are warranted to investigate the utility of MPs variation after treatment for the prediction of tumor response, prognostic outcome and survivals in NSCLC.

\section{Abbreviations}

ACD: acid citrate dextrose

ALK: anaplastic lymphoma kinase

AUC: area under curve

BMI: body mass index

CT: computed tomography

ECOG: eastern cooperative oncology group

EGFR: epidermal growth factor receptor

ETV: estimated tumor volume

ID: initial diagnosis

LC: lung cancer

MPs: microparticles

NSCLC: non-small cell lung cancer

OR: objective response

PD: progression disease

PFP: platelet free plasma

PR: partial response

PS: performance status

P/Y: pack-year

$\mathrm{R}$ : relapse

RECIST: response evaluation criteria in solid tumors

ROC: receiver operating characteristic

SCC: squamous cell carcinoma

SCLC: small-cell lung cancer

SD: Stable disease

SEM: standard error of mean

TF: tissue factor

TKIs: tyrosine kinase inhibitors

TTF-1: thyroid transcription factor 1

VEGF: vascular endothelial growth factor

\section{Acknowledgements}

The authors would like to thank Pr. Ibrahim Othman, director general of AECS, for his cooperation in this project, and Mr. Ali Mohammad for help in some statistical analyses.

\section{Conflict of Interest}

The authors state that there is no potential conflict of interest.

\section{Ethics Clearance}

Taken from the independent Ethics Committee on Human Research at Albairouni University Hospital. All procedures performed in the study involving human participants were in accordance with the principles of the Declaration of Helsinki.

\section{REFERENCES}

[1] Walters S, Maringe C, Coleman MP, Peake MD, Butler J, Young N, Bergström S, Hanna L, Jakobsen E, Kölbeck K, Sundstrøm S, Engholm G, Gavin A, Gjerstorff ML, Hatcher J, Johannesen TB, Linklater KM, Mc Gahan CE, Steward J, Tracey E, Turner D, Richards MA, Rachet B, ICBP Module 1 Working Group. Lung cancer survival and stage at diagnosis in Australia, Canada, Denmark, Norway, Sweden and the UK: a population-based study, 2004-2007. Thorax 2013; 68: 551-64.

[2] Ogawa F, Wang G, Matusi Y, Hara U, Lyoda A, Satoh Y. Risk factors for postoperative complications in the elderly with lung cancer. Asian Cardiovasc Thorac Ann. 2013; 21(3):313-8

[3] Lu T, Yang X, Huang Y, Zhao M, Li M, Ma K, Yin J, Zhan $\mathrm{C}$, Wang $\mathrm{Q}$. Trends in the incidence, treatment, and survival of patients with lung cancer in the last four decades. Cancer Manag Res. 2019; 11:943-53.

[4] Wang T, Nelson RA, Bogardus A, Grannis FW. Five-year lung cancer survival: Which advanced stage non-small cell lung cancer patients at long-term survival? Cancer. 2010; 116(3): 1518-25.

[5] Ries LAG, Eisner MP, Kosary CL, Hankey BF, Miller BA, Clegg L, Mariotto A, Feuer EJ, Edwards BK (eds). SEER Cancer Statistics Review, 1975-2002, National Cancer Institute. Bethesda, MD, based on November 2004 SEER data submission, posted to the SEER website 2005. Online available from https://seer.cancer.gov/csr/1975_2002/

[6] Pao W, Miller VA. Epidermal growth factor receptor mutations, small molecule kinase inhibitors, and non-small-cell lung cancer: current knowledge and future directions. J Clin Oncol. 2005; 23(11): 2556-68.

[7] Rosel IR, Carcereny E, Gervais R, Vergnenegre A, Massuti B, Felip E, Palmero R, Garcia-Gomez R, Pallares C, Sanchez JM, Porta R, Cobo M, Garrido P, Longo F, Moran T, Insa A, De Marinis F, Corre R, Bover I, Illiano A, Dansin E, deCastro J, Milella M, Reguart N, Altavilla G, Jimenez U, Provencio M, Moreno MA, Terrasa J, Muñoz-Langa J, Valdivia J, Isla D, Domine M, Molinier O, Mazieres J, Baize $\mathrm{N}$, Garcia-Campelo R, Robinet G, Rodriguez-Abreu D, Lopez-Vivanco G, Gebbia V, Ferrera-Delgado L, Bombaron P, Bernabe R, Bearz A, Artal A, Cortesi E, Rolfo C, Sanchez-Ronco M, Drozdowskyj A, Queralt C, de Aguirre I, Ramirez JL, Sanchez JJ, Molina MA, Taron M, Paz-Ares L. Erlotinib versus standard chemotherapy as first-line treatment for European patients with advanced EGFR 
mutation-positive non-small-cell lung cancer (EURTAC): a multicenter, open-label, randomized phase 3 trial. Lancet Onco 12012; 13: 239-46.

[8] Lynch TJ, Bell DW, Sordella R, Gurubhagavatula S, Okimoto RA, Brannigan BW, Harris PL, Haserlat SM, Supko JG, Haluska FG, Louis DN, Christiani DC, Settleman $\mathrm{J}$, Haber DA. Activating mutations in the epidermal growth factor receptor under lying responsiveness of non-small-cell lung cancer to gefitinib. N Engl J Med. 2004; 350(21): 2129-39.

[9] Yang YL, Xu LP, Zhuo FL, Wang TY. Prognostic value of micro RNA 10-bover-expression in peripheral blood of non-small cell lung cancer patients. Tumor Biol. 2015; 36(9): 7069-75.

[10] Hassanein M, Callison JC, Callaway-Lane C, Aldrich MC, Grogan EL, Massion PP. The state of molecular biomarkers for the early detection of lung cancer. Cancer Prev Res (Phila) 2012; 5(8): 992-1006.

[11] Thery C, Ostrowski M, Segura E. Membrane vesicles as conveyors of immune responses. Nat Rev Immunol. 2009; 9(8): 581-93.

[12] Celi A, Lorenzet R, Furie BC, Furie B. Microparticles and a P-selectin-mediated pathway of blood coagulation. Dis Markers. 2004; 20(6): 347-52.

[13] Lawrie AS, Harrison P, Cardigan RA, Mackie IJ. The characterization and impact of microparticles on haemostasis within fresh-frozen plasma. Vox Sang 2008; 95(3): 197-204.

[14] Van Wijk MJ, VanBave IE, Sturk A, Nieuwland R. Microparticles in cardiovascular diseases. Cardiovasc Res. 2003; 59(2): 277-87.

[15] Mallat Z, Benamer H, Hugel Benessiano J, Steg PG, Freyssinet JM, Tedgui A. Elevated levels of shed membrane microparticles with procoagulant potential in the peripheral circulating blood of patients with acute coronary syndromes. Circulation 2000; 101(8): 841-3.

[16] Martínez MC, Tesse A, Zobairi F, Andriantsitohaina R. Shed membrane microparticles from circulating and vascular cells in regulating vascular function. American Journal of Physiology-Heart and Circulatory Physiology. 2005; 288(3): H1004-H9.

[17] Pickering W, Gray E, Goodall AH, Ran S, Thorpe PE, Barrowcliffe TW. Characterization of the cell-surface procoagulant activity of $\mathrm{T}$ lymphoblastoid cell lines. J Thromb Haemost. 2004; 2(3): 459-67.

[18] Fernandes RS, Kirszberg C, Rumjanek VM, Monteiro RQ. On the molecular mechanisms for the highly procoagulant pattern of C6 glioma cells. J Thromb Haemost. 2006; 4(7): $1546-52$.

[19] Horstman LL, Ahn Y. Platelet microparticles: a wide-angle perspective. Crit Rev Oncol / Hematol 1999; 30(2): 111-42.

[20] Mostefai HA, Andriantsitohania R, Martinez MC. Plasma membrane microparticles in angiogenesis: role in ischemic diseases and in cancer. Physiol Res. 2008; 57(3): 311-20.

[21] Nomura S, Kagawa H, Ozaki Y, Nagahama M, Yoshimura C, Fukuhara S. Relationship between platelet activation and cytokines in systemic inflammatory response syndrome patients with hematological malignancies. Thrombos Research. 1999; 95(5): 205-13.

[22] Janowska-Wieczorek A, Marquez-Curtis LA, Wysoczynski M, Ratajczak MZ. Enhancing effect of platelet-derived microvesicles on the invasive epotential of breast cancer cells. Transfusion. 2006; 46(7): 1199-209.

[23] Eisenhauer EA, Therasse P, Bogaerts J, Schwartz LH, Sargent D, Ford R, Dancey J, Arbuck S, Gwyther S, Mooney M, Rubinstein L, Shankar L, Dodd L, Kaplan R, Lacombe D, Verweij J. New response evaluation criteria in solid tumors: revised RECIST guideline (version 1.1) Eur J Cancer. 2009; 45(2): 228-47.

[24] Lacroix R, Robert S, Poncelet P, Kasthuri RS, Key NS, Dignat- George F. ISTH SSC Workshop, Standardization of platelet-derived microparticle enumeration by flowcytometry with calibrated beads: Results of the International Society on Thrombosis and Haemostasis SSC Collaborative workshop. J Thromb Haemost. 2010; 8(11): 2571-4.

[25] Folkman J. Angiogenesis and apoptosis. Semin Cancer Biol. 2003; 13(2): 159-67.

[26] Folkman J. Antiangiogenesis in cancer therapy-endostatin and its mechanisms of action. Exp Cell Res 2006; 312(5): 594-607.

[27] Prandoni P, Falanga A, Piccioli A. Cancer and venous thromboembolism. Lancet Oncol. 2005; 6(6): 401-10.

[28] Koomagi R, Volm M. Tissue-factor expression in human non-small cell lung carcinoma measured by immunohistochemistry: correlation between tissue factor and angiogenesis. Int J Cancer.1998; 79(1): 19-22.

[29] Falanga A, Marchetti M, Vignoli A, Balducci D. Clotting mechanisms and cancer: implications in thrombus formation and tumor progression. Clin Adv Hematol Oncol. 2003; 1(11): 673-8.

[30] Pfister DG, Johnson DH, Azzoli CG, Sause W, Smith TJ, Baker S, Olak J, Stover D, Strawn JR, Turrisi AT, Somerfield MR. American Society of Clinical Oncology treatment of unresectable non-small-cell lung cancer guideline: update 2003. J Clin Oncol. 2004; 22(2): 330-53.

[31] Schneider J. Tumor markers in detection of lung cancer. Adv Clin Chem. 2006; 42: 1-41.

[32] Falanga A, Russo L. Epidemiology, risk and outcomes of venous thromboembolism in cancer. Hamostaseologie. 2012; 32(2): 115-25.

[33] Martinez C, Andriantsitohaina R. Microparticles in angiogenesis: therapeutic potential. Circ Res. 2011; 109(1): $110-9$.

[34] Kanazawa S, Nomura S, Kuwana M, Muramatsu M, Yamaguchi K, Fukuhara S. Monocyte-derived microparticles may be a sign of vascular complication in patients with lung cancer. Lung Cancer. 2003 39(2): 145-9.

[35] Tseng CC, Wang CC, Hsiao CC, Lu HI, Leu S, Chang HC, Huang KT, Fang WF, Chen YM, Liu SF, Yang CT, Lin MC, Yip HK. Time courses and value of circulating microparticles in patients with operable stage non-small cell lung cancer undergoing surgical intervention. Tumour Biol. 
2016; 37(9): 11873-82.

[36] Fleitas T, Martinez-Sales V, Vila V, Reganon E, Mesado D, Martin M, Gomez-Codina J, Motalar J, Reynes G. Circulating endothelial cells and microparticles as prognostic markers in advanced non-small cell lung cancer. PLoS One. 2012; 7(10): e47365.

[37] Wang CC, Tseng CC, Chang HC, Huang KT, Fang WF, Chen YM, Yang CT, Hsiao CC, Lin MC, Ho CK, Yip HK. Circulating microparticles are prognostic biomarkers in advanced non-small cell lung cancer patients. Oncotarget. 2017; 8(44): 75952-67.

[38] Tseng CC, Wang CC, Chang HC, Tsai TH, Chang LT, Huang KT, Leu S, Yen CH, Liu SF, Chen CH, Yang CT, Yip $\mathrm{HK}$, Lin MC. Levels of circulating microparticles in lung cancer patients and possible prognostic value. Dis Markers. 2013; 35(5):301-10.

[39] Najjar F, Alammar M, Al-Massarani G, Almalla N, Aljapawe A, Banat I, Ikhtiar A. Circulating endothelial cells and microparticles as diagnostic and prognostic biomarkers in small cell lung cancer. Lung cancer. 2018; 124(10):23-30.

[40] Alderfer L, Wei A, Hanjaya-Putra D. Lymphatic Tissue Engineering and Regeneration. J Biol Eng. 2018; 12:32. doi: 10.1186/s13036-018-0122-7.

[41] Yang C, Gagnon C, Hou X, Hardy P. Low density lipoprotein receptor mediates anti-VEGF effect of lymphocyte T-derived microparticles in Lewis lung carcinoma cells. Cancer Biol Ther. 2010; 10(5): 448-56.

[42] Soleti R, Benameur T, Porro C, Panaro MA, Andriantsitohaina R, Martínez MC. Microparticles harboring Sonic Hedgehog promote angiogenesis through the upregulation of adhesion proteins and proangiogenic factors. Carcinogenesis. 2009; 30(4): 580-8.

[43] Grosse A, Grosse C, Rechsteiner M, Soltermann A. Analysis of the frequency of oncogenic driver mutations and correlation with clinicopathological characteristics in patients with lung adenocarcinoma from Northeastern Switzerland. Diagn Pathol. 2019; 14(1): 18. Doi .10.1186/s 13000-019-0789-1.

[44] Pelosi G, Fraggetta F, Pasini F, Maisonneuve P, Sonzogni A, Lannucci A, Terzi A, Bresaola E, Valduga F, Lupo C, Viale G. Immunoreactivity for thyroid transcription factor-1 in stage I non-small cell carcinomas of the lung. Am J Surg Pathol. 2001; 25(3): 363-72.

[45] Puglisi F, Barbone F, Damante G, Bruckbauer M, Di Laura V, Beltrami CA, Di Loreto C. Prognostic value of thyroid transcription factor-1 in primary, resected, non-small cell lung carcinoma. Mod Pathol.1999; 12(3): 318-324.

[46] Yang B, Wang Q, Lu M, Ge Y, Zheng Y, Zhu H, Lu G. Correlations study between ${ }^{18}$ F-FDG PET/CT metabolic parameters predicting epidermal growth factor receptor mutation status and prognosis in lung adenocarcinoma. Front Oncol. 2019; 9:589. doi:10.3389/fonc.2019.00589. 